\title{
The Biochemical Changes in Bone Profile during Pregnancy
}

\author{
Awatif S. Hamdoon* , Ehsan Hassan Taha Al-Dabbagh** , Akram J. Ahmad ${ }^{\star \star \star}$ \\ *Ibn Al-Atheer Teaching Hospital for Children , ${ }^{\star *}$ Department of Biochemistry, College of Medicine , University \\ of Mosul , ${ }^{\star \star \star}$ Retired Department of Biochemistry, College of Medicine , University of Mosul , Mosul , Iraq \\ Correspondence: awatifhamdoon@gmail.com
}

(Ann Coll Med Mosul 2021; 43 (2):191-197).

Received: $3^{\text {rd }}$ May 2021; Accepted: $12^{\text {th }}$ Octo. 2021.

\begin{abstract}
Background: Metabolic processes directly affect the bone skeleton in the human body; especially during pregnancy in females. A bone profile obtained from a blood test can reveal the changes on it.

Objectives: The present study aims to estimate the changes that occur in some bone components during pregnancy and whether these changes are physiological or pathological.

Patients and methods: Blood samples were collected from 126 females who attend to Al-Hadbaa primary health care center and Al-Khansaa Hospital in Mosul city during the period from January to April 2008. These females classified into two main groups; Group-1 consists of 87 normal pregnant females which are subdivided to 3 subgroups according to their gestational age. Group-2 consists of 39 non-pregnant healthy females (control group). The biochemical parameters measured were: serum calcium, serum albumin, serum inorganic phosphorus (iP), serum alkaline phosphatase (ALP), and corrected serum calcium, and the measured data for these parameters were analyzed using different statistical methods.

Results: The total serum calcium, inorganic phosphorus and serum albumin decreased in pregnant female compared to the control group, while alkaline phosphatase activity was elevated in pregnant females compared to the non-pregnant females.

Conclusion: The increasing in ALP during pregnancy is accompanied by decreasing serum calcium in the $2^{\text {nd }}$ trimester and decreasing in iP in the $3^{\text {rd }}$ trimester that could be a pathological changes related to the bone.
\end{abstract}

Keywords: Bone profile, Pregnancy, Serum calcium, Inorganic phosphorus, Albumin, (ALP).

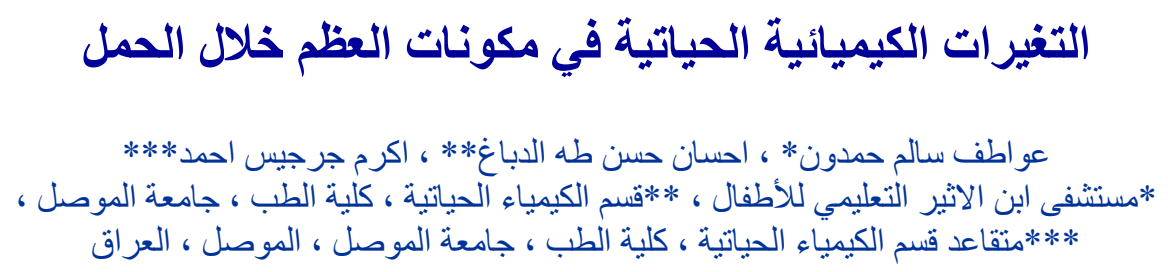

الخلاصة

الخلفية: تؤثر عمليات التمثيل الغذائي بشكل مبانشر على الهيكل العظمي في جسم الانسان وبخاصة عند فترة الحمل لدى النئ النساء

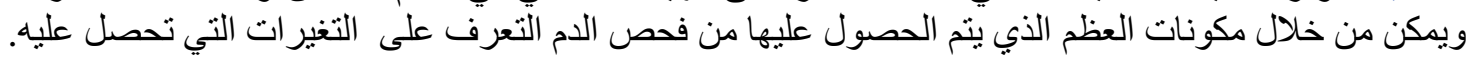

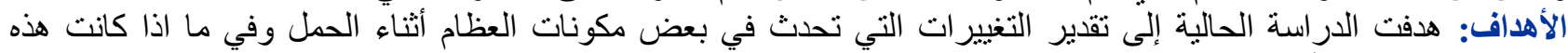
التغير ات فسيولوجية أم مرضية.

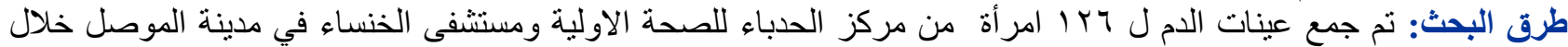

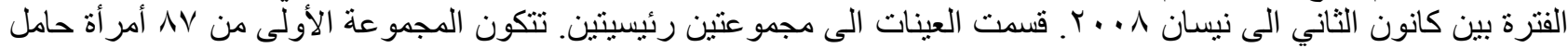

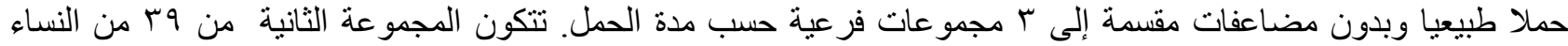

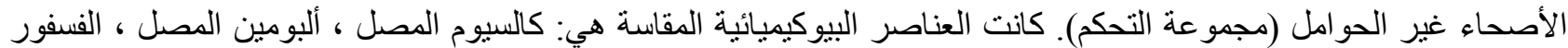

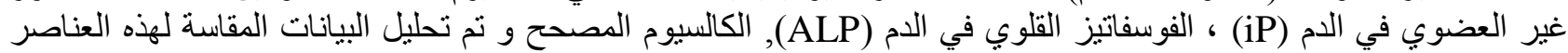
باستخدام طرق احصائية مختلفة.

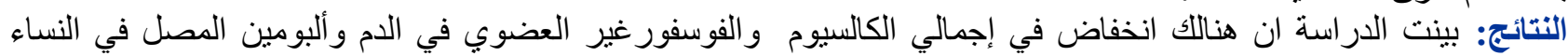

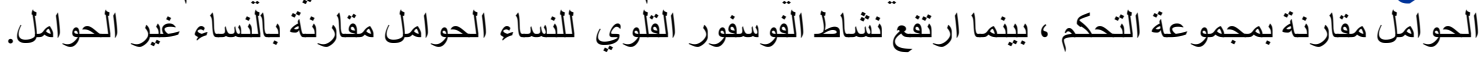




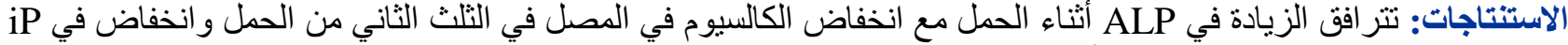

$$
\begin{aligned}
& \text { في الثلث الثالث من الحمل و الذي يمكن أن يكون عبارة عن تغير ات مرضية متعلقة بالعظأ. } \\
& \text { الكلمات المفتاحية: مكونات العظم, الحمل, كالسيوم مصل الدم, الفوسفور اللاعضوي, الالبومين, الفوسفات القاعدي . }
\end{aligned}
$$

\section{INTRODUCTION}

one remodeling is mainly a local process carried out in small area by populations of cells called bone-remodeling cells. First, osteoclasts resorb bone, and then osteoblasts lay down new bone in the same area. In females, skeletal growth continues until approximately the age of 20 , but bone mineralization may continue until the age of $35^{1}$.

Bone profile test consists of four main biochemical parameters including serum calcium, serum iP, serum albumin and serum $A_{L P}{ }^{2}$. An average full-term fetus contains $30 \mathrm{gm}$ calcium, and $20 \mathrm{gm}$ phosphorus, and about $80 \%$ of mineral accreted during the third trimester of pregnancy ${ }^{3}$, so maternal adaptation for this demand is important. Females who have sufficient calcium intakes of at least $1,000 \mathrm{mg}$ per day at the start of pregnancy do not need for further calcium supplementation, but females with suboptimal intakes of less than $500 \mathrm{mg}$ may be needed to satisfy both maternal and fetal bone requirements ${ }^{4}$. In general calcium homeostasis during pregnancy is a function of dietary intake, urinary excretion, and physiological hypoalbuminemia which is produced by hemodilution that occuring in pregnancy appears to be largely, if not completely, responsible for this condition ${ }^{5}$. Thus, the following formula is used to calculate the corrected calcium concentration $^{6}$ :

Corrected calcium $(\mathrm{mmol} / \mathrm{l})=$ measured total calcium $(\mathrm{mmol} / \mathrm{l})+0.02(40-$ albumin $(\mathrm{g} / \mathrm{l}))$

Low levels of iP before pregnancy could result in its level depletion (hypophosphataemia) and subsequently leads to some of the diseases faced by females after pregnancy ${ }^{7}$. Serum ALP is primarily extracted from the liver and bones in more than $80 \%{ }^{8}$, but in pregnancy during the second trimester, ALP activity becomes significantly higher than in the first trimester. This is primarily due to placental isoenzyme production and an increase in the bone isoenzyme, during the third trimester there is also an increase in the production of the bone isoenzyme as showed by an increase in its serum level of the six weeks post-delivery ${ }^{9}$. Osteomalacia is disorder in which mineralization of the organic matrix of the bone skeletal is defective which is due to the vitamin D deficiency. Vitamin $D$ controls calcium and phosphate absorption and metabolism; it is obtained through the direct action of sunlight on the skin $(90 \%)$ or through dietary nutrients $(10 \%)$, in particular, dairy products, eggs and fish ${ }^{10}$. In the Middle East, vitamin D deficiency is common ${ }^{11}$. Recent researches further confirms that a state of vitamin $\mathrm{D}$ deficiency (VDD), also common among females during pregnancy ${ }^{12}$, more than half of the mothers and their neonates had some degrees of vitamin $D$ deficiency ${ }^{13}$ particularly those of Asian origin $^{14}$. For example in Iranian pregnant females prevalence of VDD and VD insufficiency was $76.7 \%$ and $14.6 \%$, respectively ${ }^{15}$. Individual with darker skin is more susceptible to VDD, also osteomalacia occurred if a person with intestinal malabsorption and decrease exposure to sunlight $^{16}$.

The aims of this study were to estimating the changes that occur in some bone components during pregnancy, and try to diagnosing the cause of these changes whether physiological or pathological, in nature.

\section{PATIENTS AND METHOODS}

This study represents a case-control study. Eighty seven healthy pregnant females aged (14-42) years who attend to Al-Hadbaa primary health care center and Al-Khansaa Hospital as an outpatient. The control-group (non-pregnant females) includes thirty nine apparently healthy non-pregnant females aged (17-46) years. The females who had chronic diseases, or were taking medicines, or who had obstetric problems such as gestational diabetes, hypertensive disorder of pregnancy or premature delivery were excluded from the study. Oral consent was obtained from all females included in this study, and a complete history of both groups of females was obtained.

Determination of total calcium using colorimetric method $^{17}$, using a kit was supplied by biomerieux@SA (France). Determination of serum iP using a kit supplied by Biolabo (France). Method without deproteinisation was described by Daly and Ertingshausen ${ }^{18}$. Serum Albumin was determined using dye-binding method ${ }^{19,20}$ using kit supplied from biomerieux@Sa (France). Colorimetric determination of serum ALP activity using a kit supplied by biomerieux@SA (France) ${ }^{21}$. Standard statistical methods were used for determination of the mean (x), Z-test is used to compare between pregnant females and the 
control group, Unpaired (student's) t-test was used to compare between $1^{\text {st }}, 2^{\text {nd }}$, and $3^{\text {rd }}$ trimester each other and with the control group. Linear regression used to find the relationship between different parameters. All values quoted as the mean between observations were considered not significant at $p<0.05^{22}$

\section{RESULTS}

During the comparison between the three trimesters of pregnancy flowing results are obtained: there is no significant ( $p>0.05)$ difference in serum calcium, serum albumin, and corrected calcium among the different trimesters of pregnancy, there is a significant $(p<0.005)$ difference in serum inorganic phosphorus between $2^{\text {nd }}$ trimester $(0.97) \mathrm{mmol} / \mathrm{l}$ and $3^{\text {rd }}$ trimester $(0.83)$ $\mathrm{mmol} / \mathrm{l}$. ALP comparison shows a highly significant difference $(p<0.001)$ between $1^{\text {st }}$ trimester (5.07) K.A.U/100ml and $2^{\text {nd }}$ trimester (8.88), also a significant difference $(p<0.015)$ between $2^{\text {nd }}$ trimester (8.88)K.A.U/100ml and $3^{\text {rd }}$ trimester (11.91)K.A.U./100ml) ), and a highly significant difference $(p<0.005)$ between $1^{\text {st }}$ and $3^{\text {rd }}$ trimester as shown in table-1.

During the comparison between the pregnant and the control group, flowing results are seen: There is a highly significant decrease in serum albumin in pregnant females $(35.09 \mathrm{~g} / \mathrm{L})$ compared to the control group $(39.8 \mathrm{~g} / \mathrm{L})$. There is a highly significant $(p<0.001)$ increase in the ALP activity level in pregnant females (9.07 K.A.U./100MI) compared to the control group (6.05 K.A.U./100MI).
Table-1: The differences between different parameters of bone profile for each trimester in pregnant females.

\begin{tabular}{|c|c|c|c|}
\hline Parameter & Trimester & Mean $\pm S D$ & $\begin{array}{l}{ }^{*} \mathrm{P} \\
\text { value }\end{array}$ \\
\hline \multirow{3}{*}{$\begin{array}{l}\text { Total Ca } \\
(\mathrm{mmol} / \mathrm{l})\end{array}$} & $\begin{array}{l}1^{\text {st }} \\
2^{\text {nd }}\end{array}$ & $\begin{array}{l}2.13 \pm 0.23 \\
2.1 \pm 0.17\end{array}$ & $\begin{array}{l}< \\
0.001\end{array}$ \\
\hline & $\begin{array}{l}2^{\text {nd }} \\
3^{\text {rd }}\end{array}$ & $\begin{array}{l}2.1 \pm 0.17 \\
2.13 \pm 0.19 \\
\end{array}$ & $\begin{array}{l}< \\
0.015 \\
\end{array}$ \\
\hline & $\begin{array}{l}1^{\mathrm{st}} \\
3^{\text {rd }} \\
\end{array}$ & $\begin{array}{l}2.13 \pm 0.23 \\
2.13 \pm 0.19\end{array}$ & $\begin{array}{l}< \\
0.001\end{array}$ \\
\hline \multirow{3}{*}{$\begin{array}{l}\text { Albumin } \\
\text { (g/L) }\end{array}$} & $\begin{array}{l}1^{\text {st }} \\
2^{\text {nd }}\end{array}$ & $\begin{array}{l}36.4 \pm 12.5 \\
35.17 \pm \\
13.1\end{array}$ & $\begin{array}{l}0.550 \\
\text { NS }\end{array}$ \\
\hline & $\begin{array}{l}2^{\text {nd }} \\
3^{\text {rd }}\end{array}$ & $\begin{array}{l}35.17 \pm \\
13.1 \\
34.16 \pm \\
11.41\end{array}$ & $\begin{array}{l}0.600 \\
\text { NS }\end{array}$ \\
\hline & $\begin{array}{l}1^{\text {st }} \\
3^{\text {rd }}\end{array}$ & $\begin{array}{l}36.4 \pm 12.5 \\
34.16 \pm \\
11.41\end{array}$ & $\begin{array}{l}0.300 \\
\text { NS }\end{array}$ \\
\hline \multirow{3}{*}{$\mathrm{iP}(\mathrm{mmol} / \mathrm{l})$} & $\begin{array}{l}1^{\text {st }} \\
2^{\text {nd }} \\
\end{array}$ & $\begin{array}{l}0.91 \pm 0.15 \\
0.97 \pm 0.08 \\
\end{array}$ & $\begin{array}{l}0.390 \\
\text { NS }\end{array}$ \\
\hline & $\begin{array}{l}2^{\text {nd }} \\
3^{\text {rd }}\end{array}$ & $\begin{array}{l}0.97 \pm 0.08 \\
.0 .83 \pm \\
0.08\end{array}$ & $\begin{array}{l}< \\
0.005\end{array}$ \\
\hline & $\begin{array}{l}1^{\mathrm{st}} \\
3^{\mathrm{rd}}\end{array}$ & $\begin{array}{l}0.91 \pm 0.15 \\
0.83 \pm 0.08\end{array}$ & $\begin{array}{l}0.170 \\
\text { NS }\end{array}$ \\
\hline \multirow{3}{*}{$\begin{array}{l}\text { ALP } \\
\text { K.A.U./100MI }\end{array}$} & $\begin{array}{l}1^{\text {st }} \\
2^{\text {nd }} \\
\end{array}$ & $\begin{array}{l}9.07 \pm 3.75 \\
8.88 \pm 3.71 \\
\end{array}$ & $\begin{array}{l}< \\
0.001 \\
\end{array}$ \\
\hline & $\begin{array}{l}2^{\text {nd }} \\
3^{\text {rd }}\end{array}$ & $\begin{array}{l}8.88 \pm 3.71 \\
11.91 \pm \\
5.03\end{array}$ & $\begin{array}{l}< \\
0.015\end{array}$ \\
\hline & $\begin{array}{l}1^{\text {st }} \\
3^{\text {rd }}\end{array}$ & $\begin{array}{l}9.07 \pm 3.75 \\
11.91 \pm \\
5.03\end{array}$ & $\begin{array}{l}< \\
\ddots \ldots 1\end{array}$ \\
\hline \multirow{3}{*}{$\begin{array}{l}\text { Corrected } \\
\mathrm{Ca}(\mathrm{mmol} / \mathrm{l})\end{array}$} & $\begin{array}{l}1^{\text {st }} \\
2^{\text {nd }}\end{array}$ & $\begin{array}{l}2.35 \pm 0.17 \\
2.33 \pm 0.26\end{array}$ & $\begin{array}{l}0.840 \\
\text { NS }\end{array}$ \\
\hline & $\begin{array}{l}2^{\text {nd }} \\
3^{\text {rd }}\end{array}$ & $\begin{array}{l}2.33 \pm 0.26 \\
2.38 \pm 0.30\end{array}$ & $\begin{array}{l}0.410 \\
\text { NS }\end{array}$ \\
\hline & $\begin{array}{l}1^{\text {st }} \\
3^{\text {rd }}\end{array}$ & $\begin{array}{l}2.35 \pm 0.17 \\
2.38 \pm 0.30\end{array}$ & $\begin{array}{l}0.600 \\
\text { NS }\end{array}$ \\
\hline
\end{tabular}

*t-test

There is significant $(p<0.007)$ reduction in the level of serum calcium in pregnant females and a significant decrease in the level of iP ,but no significant difference in corrected calcium is seen as in table-2. During the comparison between the pregnant females in the $1^{\text {st }}$ trimester and the 
control group, flowing results are seen: there is no significant difference in serum calcium, corrected serum calcium, ALP, iP, but just significant difference $(p<0,014)$ in serum albumin between $1^{\text {st }}$ trimester (36.8) $\mathrm{g} / \mathrm{l}$ and (39.8) $\mathrm{g} / \mathrm{l}$ in the control group as in table -3 .

Table-2: Comparison between different parameters of bone profile between the control group and pregnant females.

\begin{tabular}{|c|c|c|c|}
\hline Parameters & $\begin{array}{l}\text { The control } \\
\text { group }(n=39) \\
\text { Mean } \pm S D \\
\text { (Range) }\end{array}$ & $\begin{array}{l}\text { Pregnant } \\
\text { Group }(n= \\
87) \\
\text { Mean } \pm \text { SD } \\
\text { (Range) }\end{array}$ & $\begin{array}{l}{ }^{*} P \\
\text { value }\end{array}$ \\
\hline $\begin{array}{l}\text { Total Ca } \\
(\mathrm{mmol} / \mathrm{l})\end{array}$ & $\begin{array}{l}2.22 \pm 0.18 \\
(1.88-2.70)\end{array}$ & $\begin{array}{l}2.11 \pm 0.23 \\
(1.88-2.72)\end{array}$ & $\begin{array}{l}< \\
0.007\end{array}$ \\
\hline Albumin(g/L) & $\begin{array}{l}39.8 \pm 5.06 \\
(32-50.2)\end{array}$ & $\begin{array}{l}35.09 \pm \\
11.22 \\
(21.45- \\
53.95)\end{array}$ & $\begin{array}{l}< \\
0.001\end{array}$ \\
\hline iP (mmol/l) & $\begin{array}{l}1.02 \pm 0.09 \\
(0.64-1.45)\end{array}$ & $\begin{array}{l}0.91 \pm 0.11 \\
(0.64-1.58)\end{array}$ & $\begin{array}{l}< \\
0.010\end{array}$ \\
\hline $\begin{array}{l}\text { ALP } \\
\text { (K.A.U./100ml) }\end{array}$ & $\begin{array}{l}6.05 \pm 2.60 \\
(3.3-10.3)\end{array}$ & $\begin{array}{l}9.07 \pm 3.75 \\
(3.51- \\
25.80)\end{array}$ & $\begin{array}{l}< \\
0.001\end{array}$ \\
\hline $\begin{array}{l}\text { Corrected } \\
\text { Ca.(mmol/l) }\end{array}$ & $\begin{array}{l}2.36 \pm 0.21 \\
(1.98-2.84)\end{array}$ & $\begin{array}{l}2.35 \pm 0.28 \\
(1.78-3.00)\end{array}$ & $\begin{array}{l}0.82 \\
\text { NS }\end{array}$ \\
\hline
\end{tabular}

* z-test

Table-3: Comparison between different parameters of bone profile in the control group and pregnant females in the $1^{\text {st }}$ trimester.

\begin{tabular}{|l|l|l|l|}
\hline Parameters & $\begin{array}{l}\text { The control } \\
\text { group } \\
\text { Mean } \pm \text { SD } \\
(\mathrm{n}=39)\end{array}$ & $\begin{array}{l}\text { First } \\
\text { trimester } \\
\text { Mean } \pm \\
\text { SD } \\
(\mathrm{n}=17)\end{array}$ & $\begin{array}{l}{ }^{*} \mathrm{P} \\
\text { value }\end{array}$ \\
\hline $\begin{array}{l}\text { Total Ca } \\
\text { (mmol/l) }\end{array}$ & $2.22 \pm 0.18$ & $\begin{array}{l}2.13 \pm \\
0.23\end{array}$ & $\begin{array}{l}0.131 \\
\mathrm{NS}\end{array}$ \\
\hline $\begin{array}{l}\text { Albumin }(\mathrm{g} / \mathrm{L}) \\
\text { iP (mmol/l) }\end{array}$ & $39.8 \pm 5.06$ & $\begin{array}{l}36.4 \pm \\
12.5\end{array}$ & $\begin{array}{l}< \\
0.014\end{array}$ \\
\hline $\begin{array}{l}\text { ALP } \\
\text { (K.A.U./100ml) }\end{array}$ & $6.05 \pm 2.60$ & $\begin{array}{l}5.07 \pm \\
1.24\end{array}$ & $\begin{array}{l}0.060 \\
\mathrm{NS}\end{array}$ \\
\hline $\begin{array}{l}\text { Corrected Ca. } \\
\text { (mmol/l) }\end{array}$ & $2.36 \pm 0.21$ & $\begin{array}{l}2.35 \pm \\
0.17\end{array}$ & $\begin{array}{l}0.791 \\
\mathrm{NS}\end{array}$ \\
\hline
\end{tabular}

${ }^{*}$ t-test
The comparison between the pregnant females in the $2^{\text {nd }}$ trimester and the control group shows the following results: There is a just significant elevation in of ALP activity in the serum of pregnant females (8.88 K.A.U./L) in comparison to the control group females (6.05 K.A.U./mL). There is a highly significant $(p<0.001)$ reduction in the level of serum albumin in the pregnant females $(35.17 \mathrm{~g} / \mathrm{L})$ in compared to the control group (39.8 $\mathrm{g} / \mathrm{L})$. There is a just significant $(p<0.05)$ reduction in the level of serum calcium in pregnant females (2.1 $\mathrm{mmol} / \mathrm{l})$ compared to the control group (2.22 $\mathrm{mmol} / \mathrm{l})$, no significant difference in iP or corrected calcium is seen between the two groups as in (Table 4).

Table-4: Comparison between different parameters of bone profile between the control group and pregnant females in the $2^{\text {nd }}$ trimester.

\begin{tabular}{|l|l|l|l|}
\hline Parameters & $\begin{array}{l}\text { The control } \\
\text { group } \\
\text { Mean } \pm \text { SD } \\
(\mathrm{n}=39)\end{array}$ & $\begin{array}{l}2^{\text {nd }} \\
\text { trimester } \\
\text { Mean } \pm \\
\mathrm{SD} \\
(\mathrm{n}=17)\end{array}$ & $\begin{array}{l}\text { *P } \\
\text { value }\end{array}$ \\
\hline $\begin{array}{l}\text { Total Ca } \\
(\mathrm{mmol} / \mathrm{l})\end{array}$ & $2.22 \pm 0.18$ & $\begin{array}{l}2.1 \pm \\
0.17\end{array}$ & $\begin{array}{l}< \\
0.008\end{array}$ \\
\hline Albumin (g/L) & $39.8 \pm 5.06$ & $\begin{array}{l}35.17 \pm \\
13.1\end{array}$ & $\begin{array}{l}< \\
0.001\end{array}$ \\
\hline iP (mmol/l) & $1.02 \pm 0.09$ & $\begin{array}{l}0.97 \pm \\
0.08\end{array}$ & $\begin{array}{l}0.283 \\
\mathrm{NS}\end{array}$ \\
\hline $\begin{array}{l}\text { ALP } \\
\text { (K.A.U./100ml) }\end{array}$ & $6.05 \pm 2.60$ & $\begin{array}{l}8.88 \pm \\
3.71\end{array}$ & $\begin{array}{l}< \\
0.001\end{array}$ \\
\hline $\begin{array}{l}\text { Corrected Ca. } \\
\text { (mmol/l) }\end{array}$ & $2.36 \pm 0.21$ & $\begin{array}{l}2.33 \pm \\
0.26\end{array}$ & $\begin{array}{l}0.560 \\
\mathrm{NS}\end{array}$ \\
\hline
\end{tabular}

${ }^{*}$ t-test

During the comparison between the pregnant females in the $3^{\text {rd }}$ trimester and the control group, flowing results are seen:

There is highly significant $(p<0.001)$ elevation in ALP activity in pregnant females (11.91) K.A.U./100ml compared to the control group (6.05) K.A.U./100ml, a highly significant $(p<0.001)$ decrease in serum phosphorus in pregnant females (0.83) compared to the control group(1.02) $(\mathrm{mmol} / \mathrm{l})$, and a significant $(p<0.002)$ decrease in serum albumin in pregnant females (34.16) $\mathrm{g} / \mathrm{L}$ compared to the control group $(39.80) \mathrm{g} / \mathrm{L}$ no significant difference in $\mathrm{s}$. calcium and corrected calcium between the two groups is seen (Table-5).

Figure-1 shows just significant $(p<0.05)$ inversed relationship between corrected serum calcium and the ALP during pregnancy and this inversed relationship mostly obvious during $2^{\text {nd }}$ trimester (Figure-2). When the correlation became highly significant $(p<0.001)$ 
Table-5: Comparison between different parameters of bone profile and product between the control group and pregnant females in the $3^{\text {rd }}$ trimester.

\begin{tabular}{|l|l|l|l|}
\hline Parameters & $\begin{array}{l}\text { The control } \\
\text { group } \\
\text { Mean } \pm \text { SD } \\
(\mathrm{n}=39)\end{array}$ & $\begin{array}{l}3^{\text {rd }} \\
\text { trimester } \\
\text { Mean } \pm \\
\text { SD } \\
(\mathrm{n}=17)\end{array}$ & $\begin{array}{l}{ }^{*} P \\
\text { value }\end{array}$ \\
\hline $\begin{array}{l}\text { Total Ca } \\
(\mathrm{mmol} / \mathrm{l})\end{array}$ & $2.22 \pm 0.18$ & $\begin{array}{l}2.13 \pm \\
0.19\end{array}$ & $\begin{array}{l}0.075 \\
\mathrm{NS}\end{array}$ \\
\hline Albumin (g/L) & $39.8 \pm 5.06$ & $\begin{array}{l}34.16 \pm \\
11.41\end{array}$ & $\begin{array}{l}< \\
0.002\end{array}$ \\
\hline $\mathrm{iP}(\mathrm{mmol} / \mathrm{l})$ & $1.02 \pm 0.09$ & $\begin{array}{l}0.83 \pm \\
0.08\end{array}$ & $\begin{array}{l}< \\
0.001\end{array}$ \\
\hline $\begin{array}{l}\text { ALP } \\
\text { (K.A.U./100ml) }\end{array}$ & $6.05 \pm 2.60$ & $\begin{array}{l}11.91 \pm \\
5.03\end{array}$ & $\begin{array}{l}< \\
0.001\end{array}$ \\
\hline $\begin{array}{l}\text { Corrected Ca. } \\
\text { (mmol/l) }\end{array}$ & $2.36 \pm 0.21$ & $\begin{array}{l}2.38 \pm \\
0.30\end{array}$ & $\begin{array}{l}0.670 \\
\mathrm{NS}\end{array}$ \\
\hline
\end{tabular}

${ }^{*}$ t-test

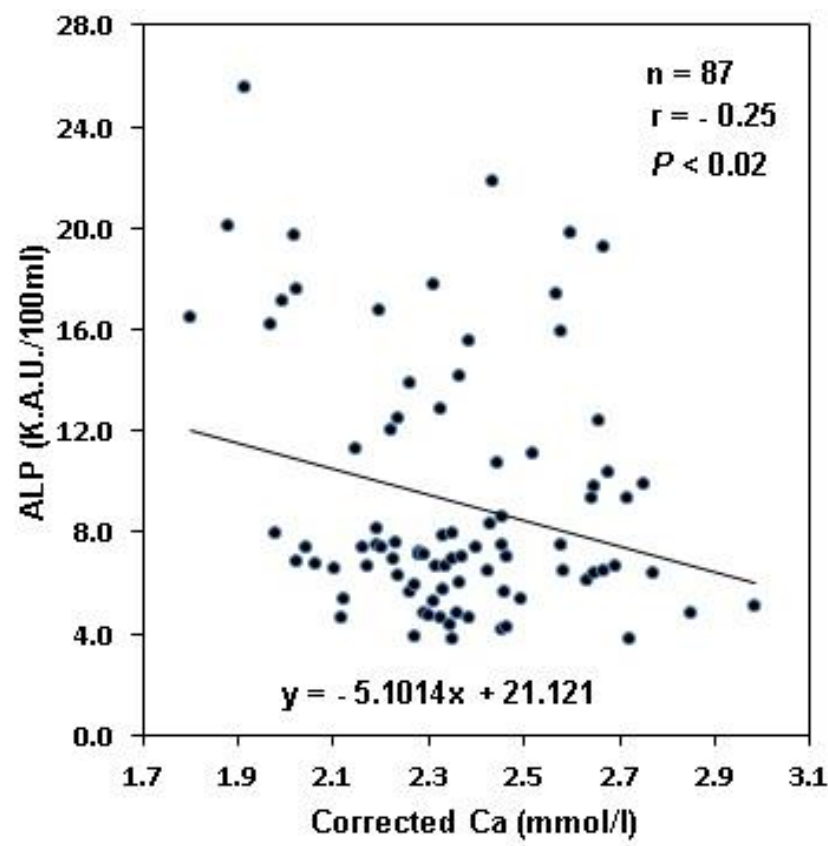

Figure-1: The relationship between corrected serum calcium (measured calcium $(\mathrm{mmol} / \mathrm{l})$ + $0.02[40$ - albumin $(\mathrm{g} / \mathrm{l})]$ ) and ALP during pregnancy

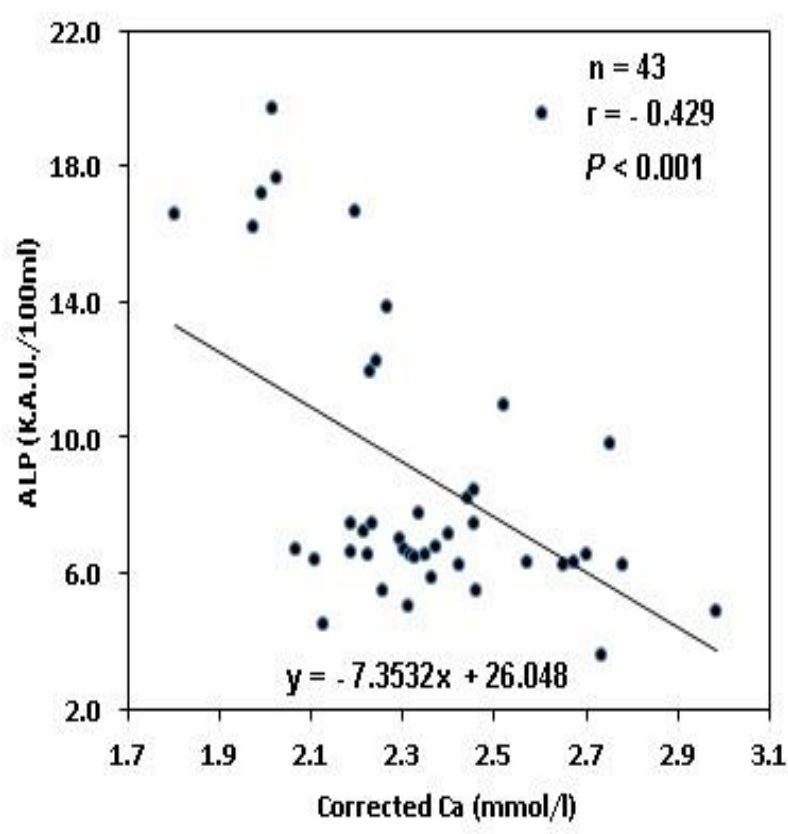

Figure-2: The relationship between corrected serum calcium and ALP during $2^{\text {nd }}$ trimester of pregnancy

\section{DISCUSSION}

Hypocalcaemia in late pregnancy is highly prevalent $(59 \%)$ among females in reproductive period $^{23}$. In the present study serum calcium was tend to decrease throughout pregnancy, and the difference was just significant compared to the control group, especially in the $2^{\text {nd }}$ trimester compared to the control group. The conclusion of this study was similar to a study was done in the west of Iran, in which (26.4\%) of pregnant females found to be hypocalcaemic ${ }^{24}$, other report found that maternal serum calcium does not vary with increase in the gestational age, and that there is an increase in serum calcium in pregnant females compared to the non-pregnant controls but this report was done in a developed country ${ }^{25}$. Serum albumin shows no significant difference among different time of pregnancy, but a highly significant difference when compare serum albumin in pregnant females to the control group when $(p<0.001)$, this result is in agreement with the study that found a marked decrease in serum albumin and this decrease is more in those who gestational age less than 37 wks. This is in contrary to the fact that serum albumin will decrease as the pregnancy progresses due to the dilutional effect of increase maternal plasma volume over increase total serum albumin during pregnancy ${ }^{26}$, moreover this is in agree with another study done on Sudanese pregnant females that showed significant decrease in serum albumin during pregnancy ${ }^{27}$. 
Regarding serum iP the difference between the pregnant group and the control group was significant and the much affection appears obviously through the last trimester when the difference between $3^{\text {rd }}$ trimester and the control group $(p<0.001)$. The same result obtained in a study done on Saudi pregnant females showed that iP decreased in pregnancy ${ }^{5}$. In Nigerian study serum iP differences was very highly significant between control and pregnant and between the three trimesters with each other ${ }^{23}$. These results support that the maternal urinary execration of iP levels increased during the third trimester of pregnancy ${ }^{28}$.

Serum ALP activity shows highly significant difference $(p<0.001)$ when compare it in the different trimester and with both $2^{\text {nd }}$ and 3 rd trimesters compared to the control group value, this because in pregnant females, the activity of the placental isoenzyme of ALP is increased. In the last trimester, the increase may be up to 4 times than the normal values ${ }^{29,30}$.

Although the corrected calcium showed insignificant difference in this result there was an inversely correlation between serum ALP and corrected serum calcium (Figure-1). This inversed correlation was seen also during the $2^{\text {nd }}$ trimester (Figure-2). This inversed correlation is parallel to the hypocalcaemia that seen during pregnancy especially in the $2^{\text {nd }}$ trimester. This means that although apparently insignificant changes in corrected calcium but there is a tendency of ALP to increase.

\section{CONCLUSIONS}

The current study explained that the hypoalbuminaemia due to dilutional effect of pregnancy start early from $1^{\text {st }}$ trimester. ALP increases during pregnancy accompanied by calcium decreasing in the $2^{\text {nd }}$ trimester, while in the $3^{\text {rd }}$ trimester ALP increasing is accompanied by iP decreasing.

The increasing ALP in pregnancy is not always considered as normal physiological changes explained by placental isoenzyme, but if it is accompanied by decreasing level of other elements of bone profile osteomalacia should not be forgotten.

\section{REFERENCES}

1.Ganong, WF. Review of medical physiology. 21st ed. McGraw-Hill. Com.Inc.2005; 391p.

2. Machingura PI, Muringai K, Chikwasha V. Serum bone markers in pregnant women at Parirenyatwa Group of Hospitals and Chitungwiza Central Hospital, Bangladesh Journal of Medical Science. 2015; 14 (4): 363366. doi: http://dx.doi.org/10.3329/bjms.v14i4.20080.

3. Kovacs CS. Maternal mineral and bone metabolism during pregnancy, lactation, and post-weaning recovery. Physiol Rev. 2016; 96: 449-547. doi:10.1152/physrev.00027.2015.

4. Hacker AN, Fung EB ,King JC. Role of calcium during pregnancy: maternal and fetal needs. Nutrition Reviews. 2012; 70(7): 397-409. doi:10.1111/j.1753-4887.2012.00491.x.

5. Ardawi MS, Nasrat NA, BA'Aqueel HS. Calciumregulating hormones and parathyroid hormonerelated peptide in normal human pregnancy and postpartum: a longitudinal study. Eur J Endocrinol. 1997; 137(4): 402-409. doi: 10.1530/eje.0.1370402.

6. Gowenlock AH. Varley's Practical clinical biochemistry. 6th ed. Heinemann Medical Books. London, UK. 1988; 1050p.

7.Ishmael UC, Rashid SS, Chibuike UB, Basheer EA. Effects of pregnancy on serum calcium, magnesium and inorganic phosphate ions in relation to osteo-diseases. Journal of Biotechnology Science Research. 2014; 1(2): 22-29.

8. Llorente-Pelayo S, Docio P, Lavín-Gómez BA, García-Unzueta MT, Cuevas GI, Rubia L, et al. Modified serum ALP values and timing of apparition of knee epiphyseal ossification centers in preterm infants with cholestasis and risk of concomitant metabolic bone disease of prematurity. Nutrients. 2020; 12(12): 3854: doi: 10.3390/nu12123854.

9. Al-khayat TH, Al-Quzweny RM. Variation of alkalinephosphatase and transaminases levels in different trimesters of pregnancy Iraqi women. Medico-legal Update. 2020; 20(1): 1283-1288. doi: https://doi.org/10.37506/mlu.v20i1.551.

10. Australian Government/ Department of Health. Clinical Practice Guidelines: Pregnancy care. (c) Australian Government Department of Health. 2019; 319P.

11. Bhowmik B, Siddiquee T, Mdala I, Nesa LQ, Shelly SJ, Hassan Z, et al . Vitamin D3 and B12 supplementation in pregnancy. Diabetes Research and Clinical Practice. 2021; 174(1 08 $7 \quad 2 \quad 8): 1-14$. https://doi.org/10.1016/j.diabres.2021.108728.

12. Al Mahfooth WF, Lafta RO, Khuoo AN . A Study of Vitamin D Level in Pregnancy and the 
Effect of its Deficiency on Pregnancy Outcome. J Women's Health Care. 2020; 9(6): 1-6. doi:10.35248/2167-0420.20.9.500.

13. Abbasian M, Chaman R, Amiri M, Ajami MS, Jafari-Koshki T, Rohani $H$, et al . Vitamin D deficiency in pregnant women and their neonates. Glob J Health Sci. 2016; 8(9):54008. doi: 10.5539/gjhs.v8n9p83.

14. Williams A F. Vitamin D in pregnancy: an old problem still to be solved? Arch Dis Child. 2007; 92(9): 740-741. doi: 10.1136/adc.2007.120774.

15. Sepandi M, Esmailzadeh $S$, Hosseini MS, Hashemi SR, Abbaszadeh S, Alimohamadi Y, et al . Prevalence of vitamin $D$ deficiency among iranian pregnant women. Nutrition and Dietary Supplements. 2020; 12: 97-102. doi: http://doi.org/10.2147/NDS.S261229.

16. Miguel A. Montoro-Huguet, Belloc B, Domínguez-Cajal M . Small and Large Intestine (I): Malabsorption of Nutrients. Nutrients. 2021; 13: 1254. https://doi.org/10.3390/nu13041254.

17. Gindler EM , King JD. Rapid colorimetric determination of calcium in biologic fluids with methylthymol blue. Am J Clin Pathol. 1972; 58(4):376-82. doi: 10.1093/ajcp/58.5.376.

18. Daly JA, Ertingshausen G. Direct method for determining inorganic phosphate in serum with the "CentrifiChem". Clin Chem.1972; 18(3):263265. PMID: 5020822.

19. Doumas BT, Watson WA, Biggs HG. Albumin standards and the measurement of serum albumin with bromcresol green. Clin Chim Acta, 1971; 31(1):87-96. doi: 10.1016/00098981(71)90365-2.

20. Drupt F. Colorimetric method for determination of albumin. Pharm. Bio.1974; 9:777.

21. Kind PR , King EJ. Estimation of plasma phosphatase by determination of hydrolysed phenol with amino-antipyrine. J Clin Pathol. 1954; 7(4): 322-326. doi: 10.1136/jcp.7.4.322.

22. Andrade $C$. The $P$ value and statistical significance: misunderstandings, explanations, challenges, and alternatives. Indian J Psychol Med. 2019; 41(3): 210-215. doi: 10.4103/IJPSYM.IJPSYM 19319.

23. Ajong $A B$, Kenfack $B$, Ali IM, Yakum MN, Telefo PB. Prevalence and correlates of low serum calcium in late pregnancy: A cross sectional study in the Nkongsamba Regional Hospital. PLoS ONE.2019; 14(11): e0224855. doi: 10.1371/journal.pone.0224855.

24. Qhotbi N, Molanaei N, Mosaed P, Sedighi GV, Hasani, S. Vitamin D, calcium and phosphorus status of pregnant females and their newborns in west Iran. Rawal Med.J. 2007; 32(1): 17-20.

25. Ikechukwu ICh, Chinyere UAO, Uzoma ICh, Gilbert NO, Hughs MA, Ekenedirichukwu OJ, et al . Does Pregnancy actually affect serum calcium and inorganic phosphate levels? Shiraz E-Med.J. 2005; 6(1): 29-34.

26. Correia-Branco A, Rincon MP, Pereira LM, Wallingford MC. Inorganic phosphate in the pathogenesis of pregnancy-related complications, Int $\mathrm{J}$ Mol Sci. $2020 ; 21(15): 5283 . \quad$ doi: 10.3390/ijms21155283.

27. Al Ghazali B, Al-Taie AA, Hameed RJ. Study of the clinical significance of serum albumin level in Preeclampsia and in the detection of its severity. American Journal of BioMedicine, 2014; 2(8): 964-974. doi:10.18081/2333-5106/016-110120.

28. Mahdi MA, Elgzoly EA, Ibrahim AA, Osman HS, Mohamed RA. Measurement of plasma total protein, albumin and urea in healthy Sudanese pregnant females. World Journal of Pharmaceutical Research. 2018; 7(2): 204-209.

29. Fernandez, NJ, Kidney, BA. Alkaline phosphatase: beyond the liver, Vet Clin Pathol. 2007; 36(3):223-33. doi: 10.1111/j.1939165x.2007.tb00216.x.

30. Stanley Z, Vignes K, Marcum M. Extreme elevations of alkaline phosphatase in pregnancy: A case report, Case Rep Women's Health. 2020; 27(5): e00214. doi: 10.1016/j.crwh.2020.e00214. 